\title{
The Construction Industry as the Subject of Implementing Corporate Social Responsibility (the Case of Poland)
}

\author{
Arnold Bernaciak ${ }^{1, *}$, Małgorzata Halaburda ${ }^{1}$ and Anna Bernaciak ${ }^{2}$ \\ 1 Institute of Economics and Finance, WSB University in Poznan, 61-895 Poznan, Poland; \\ malgorzata.halaburda@wp.pl \\ 2 Institute of Management, Poznan University of Economics and Business, 61-875 Poznan, Poland; \\ anna.bernaciak@ue.poznan.pl \\ * Correspondence: arnold.bernaciak@wsb.poznan.pl; Tel.: +48-501076696
}

Citation: Bernaciak, A.;

Halaburda, M.; Bernaciak, A. The Construction Industry as the Subject of Implementing Corporate Social Responsibility (the Case of Poland). Sustainability 2021, 13, 9728. https:// doi.org/10.3390/su13179728

Academic Editor: David K. Ding

Received: 17 July 2021

Accepted: 26 August 2021

Published: 30 August 2021

Publisher's Note: MDPI stays neutral with regard to jurisdictional claims in published maps and institutional affiliations.

Copyright: (c) 2021 by the authors. Licensee MDPI, Basel, Switzerland. This article is an open access article distributed under the terms and conditions of the Creative Commons Attribution (CC BY) license (https:// creativecommons.org/licenses/by/ $4.0 /)$.

\begin{abstract}
Companies of the construction sector face a significant impact on the environment and people: consume massive amounts of natural resources, emit pollutants, and generate large amounts of waste, are a place of danger and accidents at work. It is well established that implementation of CSR principles can lead to several economic, social, and environmental benefits. This is shown by numerous studies carried out in various countries among companies from different sectors of the economy. The aim of the article is to identify the most determining activity motives, barriers, and effects of implementing CSR principles by enterprises of the Polish construction sector and to determine the differences in this aspect between large, medium, and small-size enterprises. A questionnaire survey covered 177 enterprises. Factor like size, a place of origin, type of capital (domestic, foreign), annual turnover and time in the market were also considered. The documents of enterprises, reports, statistical data, and internal regulations of companies were also examined. The research results show large variations in terms of motives, barriers and expected benefits out of the implementation of CSR principles in various types of construction enterprises. There are different ways of implementing CSR principles and incorporating this area into organizational structures of the companies. A special role is assigned to large enterprises that show the greatest commitment in this scope. They become sources of good practices for other types of enterprises.
\end{abstract}

Keywords: corporate social responsibility; construction sector; strategy; motives; barriers; effects

\section{Introduction}

The construction sector is characterised by a number of features that distinguish it from other sectors of the economy. Many studies show that, together with related sectors, it is a key contributor to job creation and GDP [1-5]. At the same time, it is very vulnerable to changes in the economic situation and changes in the labour market. It is even pointed out that the construction sector is characterised by a duality-on one hand, it is parametrised by market indicators of the end product, i.e., to a large extent the real estate market, while on the other hand, it is determined in parallel by the market for prices of construction products and services, the labour market, including lower-skilled workers, and the capacity and competitiveness of construction enterprises themselves.

The specificity of the construction sector is mainly determined by the high dynamics of changes in the construction process (large number and variety of actors involved and multiple processes), fierce price competition and capital intensity, contractor expertise, high labour intensity, exceptional importance of the public sector and long life of the final product [6]. These elements influence its volatility, its level of risk and its diversification. Faced with such characteristics, the functioning of the construction sector in the context of its relationship with the environment becomes a major challenge. Many researchers argue that it is an activity with high environmental pressure, wastefulness, limited environmental and social efficiency, characterized by reactivity [7]. 
In the case of the construction sector, the topic of corporate social responsibility (CSR) is therefore of particular relevance, as it is more often exposed than other sections of the economy to violations of environmental or health and safety requirements, and communities, employees and socially conscious clients expect firms to demonstrate they are good corporate citizens $[1,8,9]$. Construction contributes to a heavy burden on the environment, as it causes significant consumption of natural resources and is a source of numerous pollutants and waste [10]. The construction sector is also burdened with numerous health risks for workers [11,12]. According to statistics from many countries, construction has the highest number of fatal and serious accidents.

The justification for undertaking CSR activities in the construction sector may be the legitimacy theory, which "is a mechanism supporting organizations in implementing and developing voluntary social and environmental disclosures in order to fulfil their social contracts that enables the recognition of their objectives and the survival in a jumpy and turbulent environment" [13]. In effect social perception of the organization's activities is reported in line with the expectations of the society. At the same time, there is a lot of evidence that compliance with CSR and other corporate governance principles, as well as their reporting to the public, is reflected in the perception of the organization and improvement of its image $[14,15]$.

The literature studies indicate that, so far, no research has been conducted on the motives of Polish construction sector companies in implementing the CSR concept. Although the results of a number of studies aimed at determining the level of implementation of the social responsibility concept in Polish enterprises are present in the literature [16-21], they do not apply to the construction industry. The barriers that hinder construction enterprises from being active in CSR have not been identified. There is also a lack of studies that would indicate the effects that construction enterprises expect from the implementation of socially responsible activities undertaken. There is an increasing number of social responsibility reports presented by various industries, as well as a growing number of literature items describing ways of implementing the CSR concept, presented as business models. Although these models present the level of implementation of social responsibility, they do not show the determinants of CSR implementation in construction enterprises. This is a significant research gap, which inspired the subject of this article. Due to the fact that no research was carried out in Polish construction industry companies regarding their relations with CSR before, this study is unique. The presented results and conclusions may be an interesting comparative material for other economies of Central and Eastern Europe, as well as other industries in these countries. The study is part of a broader and constantly developing stream of research on CSR in the construction sector, concerning other countries, with particular consideration of the scale of the conducted activity and its connections with the tendency to implement CSR.

The article tends to identify the role that CSR principles play in the activities of Polish construction sector enterprises. The main aims of the article are to determine the degree of implementation of CSR postulates, to identify the motives that construction enterprises follow when deciding to implement CSR principles, to identify barriers and to determine the effects of implementation of CSR principles by construction companies. The differences between large, medium, and small-size enterprises in that scope, are determine.

\section{Literature Review}

An important area of CSR activities of construction enterprises are activities for the local community and the immediate environment. Construction investments often interfere in the daily lives of the inhabitants. Dialogue with social groups exposed to inconvenience is therefore necessary [11].

It is pointed out that when more and more companies publish information about their CSR activities, at the same time any negative aspects of their activities are concealed [22]. The reason for this attitude is the desire to maintain a positive image and desired reputation. Within a single company, one can encounter examples of both social responsibility and 
business irresponsibility. And construction is one of the sectors that are particularly important from the point of view of their impact on the natural environment and society, moreover, playing an important role in the contemporary economy, contributing to its development and stabilisation. Moreover, the construction industry is one of the largest consumers of intermediate products (raw materials, chemicals, electrical and electronic equipment, etc.) and related services [23]. The construction industry faces numerous challenges in terms of inter alia, resource efficiency, reducing the negative impact of buildings on the environment and human health, and reducing waste and pollution.

However, while CSR research in construction has accelerated in recent years, it remains fragmented and unconceptualised, as being confrontational [24]. Indicating the way of implementing CSR goals in building the strategy of enterprises in the construction industry as well as defining the scope, motives, barriers, and effects of implementing CSR principles by enterprises are the main objectives of the considerations undertaken.

Consideration of the issue of motivation of organisations to engage in CSR has been performed for a long time. They largely focus on answering the question: do companies use this tool as a result of their beliefs and values, or are they motivated by purely utilitarian reasons? Liston-Heyes and Certon [25] argue that few companies engage in CSR activities driven by altruistic motivations [26]. In fact, companies aim to achieve both their own benefits, as well as positively influence the company's environment [27-29].

Currently, the most common division is into two groups of determinants affecting the use of CSR by enterprises-internal (they are shaped by the internal environment of the organisation) and external (institutional, created by the environment in which a given company operates). Both groups of factors can simultaneously stimulate and block entrepreneurial activity [30], and consequently determine the involvement of enterprises in CSR activities. The group of internal factors includes the size of the entity, capital resources, human resources, origin of capital and time on the market and attitudes of managers [30-36].

External factors, defined by Kudlak [37] (p. 18) as 'a set of formal and informal factors that influence the level, scope, and form of enterprises' engagement in CSR', include: existing legal regulations, institutional effectiveness, social pressures and expectations, the behaviour of other enterprises and organisations (including competitors, suppliers, contractors, investors contractors), informal social norms (reciprocity principle, customs, cognitive-cultural patterns) [37-41].

In terms of validating enterprises' motivations to implement CSR, depending on the industry and the region, different factors play a dominant role [40-47]. An interesting analytical perspective is also to inscribe intrinsic motivations in the mechanism of moral attitudes, which holds that CSR is a moral duty of companies towards society, and extrinsic in strategic motives, which holds that CSR contributes to the financial success of the company in the long run [48]. In a review study adopting this perspective Grimstad, Glavee-Geo and Fjørtoft [49], addressed the situation of small and medium-sized enterprises (SMEs) by asking: do SMEs' intrinsic motivation drive CSR activities more than extrinsic motivation? And their findings suggest that SMEs' intrinsic motivation drives CSR more than extrinsic motivation. Similar results were also obtained by Graafland and van de Ven [48] or Graafland, Kaptein and Mazereeuw [50].

However, the specificity of the construction industry requires the issue of CSR implementation in its enterprises to be considered in a separate context. It results from the separateness of this sector described above, which on one hand can be analysed in relation to enterprises and commercial undertakings, and on the other in relation to the activity of public authorities that award contracts for construction projects. As a result, there is a specific mix of internal and external factors, reflected in the strategies, management styles and objectives of the companies in the sector, as well as in the legal regulations that determine them, the nature of the markets or the requirements of the main users of the services. As Losemore and Lim [24] argue 'construction industry companies need to practically adjust and adapt their CSR strategies to fit with the constantly changing political, social, cultural, 
environmental, and economic profiles of local communities and the requirements of clients and local governments'. These requirements can fit into the trend of socially responsible procurement (SRP), which utilises government expenditure on construction procurement as a means of generating social value from construction activities [51,52].

Authors of a broad review of research findings, relating to drivers, motivations, and barriers for CSR implementation by construction enterprises, Zhang, Oo, \& Lim [53] point to a number of categories (sub-themes) that can be analysed for each of these areas (Table 1). These refer to both factors external and internal to the enterprise.

Table 1. The conceptualization of drivers, motivations and barriers of implementing CSR in the construction sector in developing and developed countries.

\begin{tabular}{|c|c|c|}
\hline Category & Sub-Themes & Most Frequent Attributes \\
\hline Drivers & $\begin{array}{c}\text { policy pressure, market } \\
\text { pressure, } \\
\text { innovation and technology } \\
\text { development }\end{array}$ & $\begin{array}{l}\text { Critical stakeholders' (e.g., clients, } \\
\text { investor, shareholders customers, } \\
\text { end-users, joint venture) demand or } \\
\text { pressure, market shift; Competitor } \\
\text { pressure (e.g., competitors' CSR } \\
\text { strategies) }\end{array}$ \\
\hline Motivations & $\begin{array}{l}\text { financial benefits, branding, } \\
\text { reputation and image, } \\
\text { relationship building, } \\
\text { organizational culture, } \\
\text { strategic business direction }\end{array}$ & $\begin{array}{l}\text { Branding, image management, public } \\
\text { reputation; Public } \\
\text { expectation/pressure, media pressure; } \\
\text { Organizational culture and awareness: } \\
\text { core business value, personal values of } \\
\text { the founder or entrepreneur, ethical } \\
\text { beliefs and consideration, doing the } \\
\text { right thing, business imperatives }\end{array}$ \\
\hline Barriers & $\begin{array}{l}\text { government policy, construction } \\
\text { enterprise (business } \\
\text { organization), } \\
\text { the attributes of CSR, the } \\
\text { stakeholder perspective, the } \\
\text { construction industry }\end{array}$ & $\begin{array}{l}\text { Lack of awareness, knowledge, and } \\
\text { information within the organization; } \\
\text { Lack of capacity and expertise; Lack of } \\
\text { internal resources; Lack of strategic } \\
\text { guidance and support from senior } \\
\text { leaders or managers within the } \\
\text { organization; The negative attitude } \\
\text { within the organization }\end{array}$ \\
\hline
\end{tabular}

Source: own elaboration according to [53,54].

As a result, they point to the key issues, most frequently raised in the literature, which are part of the groups of drivers, motivations and barriers (referred to as sub-themes or perspectives) and also present their attributes in the form of specific conditions in a given group. The review shows that companies are far more likely to point to factors that are barriers on the side of the business organisation than to drivers and motivations. The key barriers identified are shortcomings that lie directly with the business such as lack of awareness, knowledge, and information within the organization, lack of capacity and expertise, lack of internal resources or lack of strategic guidance and support from senior leaders or managers within the organization, all contribute to the overall barrier that is the negative attitude within the organization [55-58].

\section{Materials and Methods}

The research assumption adopted is that the variables differentiating the behaviour of Polish construction sector enterprises towards CSR requirements are: the size of employment, annual turnover, capital ownership and time of market presence. In the study, the size of enterprises was adopted as a differentiating factor of their behaviour. Other variables were used only in the analysis of the scale of implementation of CSR principles.

The following research hypotheses are posed:

1. Enterprise size, turnover, time on the market and origin of capital are factors that differentiate the degree of implementation of principles in individual CSR areas $[7,42,47,53,54]$. 
2. Large enterprises in the field in question influence the organizational structure of the entity [43-45,58].

3. Small and medium enterprises implement postulates and principles of Corporate Social Responsibility, to a large extent, in a non-formalized manner. Such activities are not part of the company's strategy [30,41,42,47,59].

4. For large companies implementing CSR postulates, image benefits are very important, and financial benefits may be distant in time [20,46].

5. The main barriers related to the implementation of CSR in small and medium enterprises relate to restrictions in the field of knowledge in this scope [35,60].

6. Owners and managers of small construction enterprises perceive CSR activities only as a cost that will not bring any additional benefits.

The study was carried out by means of a diagnostic survey. The techniques applied were face-to-face questionnaire and online survey (CASI-computer assisted selfinterviewing-technique). An original survey form was used. The form consisted of closed and semi-open questions, arranged in thematic blocks concerning motivating factors, barriers, benefits and disadvantages of implementing CSR principles. The questions used a nominal scale (two-level), a five-point semantic scale and an ordinal measurement scale (five-point Likert scale). Additionally, open-ended questions were included in part of the questionnaire to elaborate on the respondents' answers.

The subjects of the analysis were small construction companies (with 10-49 employees), medium-sized companies (with 50-249 employees) and large companies (with 250 or more employees). Micro companies were excluded from the survey. Organisational units were considered:

- conducting a registered business activity,

- whose activities, in accordance with the Polish Classification of Activities, are carried out under section F, division 41: works related to the erection of buildings,

- not in bankruptcy or liquidation,

- operating in Poland.

The sample for the study was selected using the purposeful method. A random selection was affected by the unavailability of a sampling frame and the prohibitively high financial costs of conducting the survey. The sample size was determined based on two key considerations. Firstly, we took into account the specificity of the analysed companies and difficulty in obtaining relevant data-difficulty in convincing representatives of companies from the section to take part in the research. Secondly, statistical requirements regarding the minimum sample size were taken into account. It was assumed that the minimum sample size should be 100-200. This type of sample size is usually required when many statistical tests are applied and is appropriate when we do not have to deal with too detailed presentation of results (high level of spatial aggregation or less precisely defined domain-cross-sections) [61] (p. 16). Finally, in the survey conducted, the sample size was 177, of which 106 were small companies, 49 were medium-sized companies and 22 were large companies.

In connection with the adopted selection of the research sample, it should be borne in mind that the obtained results may be burdened with an error, the size of which cannot be determined as precisely as in the case of random samples. The obtained results should therefore be interpreted with particular care.

On the basis of the data obtained from the EMIS, Amadeus and ALEO databases, an own list of enterprises (database) was drawn up, to which invitations to participate in the study were sent out with a questionnaire form via e-mail and traditional mail (The databases mentioned are: EMIS (Emerging Markets Information Service)—a web service containing information on more than 80 emerging markets worldwide, whose provider is Euromoney Polska S.A., Amadeus-an international database containing information on more than 20 million companies from 43 European countries, leading providers: InfoCredit and Bureau van Dijk Electronic Publishing, ALEO—a Polish database containing data on all companies registered in the KRS [National Court Register] and CEIDG [Central 
Registration and Information on Business], provided by ING Usługi dla Biznesu S.A.-part of the ING Group. It should be emphasised, however, that these databases do not contain all companies from the PKD [Polish Classification of Activity] section analysed in the study, therefore the obtained list could not be treated as a sampling frame. This justified the purposeful sample selection used in the study). In some cases, especially large companies, a telephone contact was made. Invitations to the survey were addressed to persons directly responsible in a given organisational unit for Corporate Social Responsibility issues, the owner of the company, or a relevant (in terms of form and subject matter) person at the top management level. In case of lack of response from the companies, messages reminding about the previous request were sent at least twice.

2047 invitations were sent out. As a result of own research, empirical material was obtained from a total of 177 construction companies. The return rate of the questionnaires was $8.65 \%$.

The time scope of the study covered the period from February to November 2019. The surveyed sample was dominated by small-sized enterprises with between 10 and 49 employees and they accounted for $59.89 \%$. The share of medium-sized enterprises was represented by $27.68 \%$ of entities. The remaining group accounting for $12.43 \%$ of the research sample belonged to the category of large enterprises.

Comparing the structure of the general population with the surveyed sample of enterprises, one finds structural differences between particular size categories of enterprises. The share of small companies in the general population is higher by 28.66 percentage points than the share of entities of this size in the research sample. In case of medium-sized and large enterprises, their share in the survey was more numerous than the information on the general population indicated (Table 2). Finally, the selection of the sample was disproportionate and resulted from the adopted purposeful selection of entities.

Table 2. Comparison of the structure of the general population and the research sample.

\begin{tabular}{ccccc}
\hline Employment Volume & $\begin{array}{c}\text { Size of the General } \\
\text { Population }\end{array}$ & $\begin{array}{c}\text { Share of Enterprises } \\
\text { in the General } \\
\text { Population (\%) }\end{array}$ & $\begin{array}{c}\text { Number of } \\
\text { Enterprises Surveyed }\end{array}$ & $\begin{array}{c}\text { Share of Enterprises } \\
\text { in the Test Sample (\%) }\end{array}$ \\
\hline from 10 to 49 & 6543 & 88.55 & 106 & 59.89 \\
from 50 to 249 & 794 & 10.75 & 49 & 27.68 \\
250 and above & 52 & 0.70 & 122 & 100 \\
\hline$\Sigma$ & 7389 & 100 & & 177 \\
\hline
\end{tabular}

Differentiation of the sample in terms of the basic characteristics of enterprises allows for taking into account a number of variables in the analyses (Table 3).

Among the enterprises that took part in the survey, most of the enterprises use exclusively domestic capital (87.57\%). The remaining enterprises declared mixed ownership $(9.04 \%)$, and the least capital belonging exclusively to foreign entities (3.39\%). The survey was dominated by enterprises with an annual turnover of up to EUR 10 million (64.41\%). The research sample also included entities whose annual turnover in the surveyed year is higher than EUR 10 million, but does not exceed EUR 50 million (24.29\%). The least numerous group are enterprises whose annual turnover exceeds EUR 50 million (11.30\%). Most of the entities participating in the study have been operating in the market for more than 20 years $(47.46 \%)$, while the smallest group was represented by companies with seniority between 10 and 20 years $(20.34 \%)$. The remaining companies were those with up to 10 years of presence on the market $(32.20 \%)$. 
Table 3. Characteristics of the research sample in various sections.

\begin{tabular}{|c|c|c|c|}
\hline \multicolumn{2}{|c|}{ Surveyed Enterprises } & \multicolumn{2}{|c|}{$\mathrm{N}=177$} \\
\hline \multicolumn{2}{|r|}{ Criterion } & $\begin{array}{l}\text { Number of } \\
\text { Observations }\end{array}$ & $\begin{array}{c}\text { Percentage of } \\
\text { Observation in the } \\
\text { Research Sample (in \%) }\end{array}$ \\
\hline \multirow{3}{*}{$\begin{array}{l}\text { Origin of capital } \\
\text { (ownership form) }\end{array}$} & only domestic & 155 & 87.57 \\
\hline & only foreign & 6 & 3.39 \\
\hline & mixed with foreign capital participation & 16 & 9.04 \\
\hline \multirow{3}{*}{$\begin{array}{l}\text { Annual turnover in the } \\
\text { year under review in } \\
\text { EUR million }\end{array}$} & up to EUR 10 million & 114 & 64.41 \\
\hline & above EUR 10 million up to EUR 50 million & 43 & 24.29 \\
\hline & over EUR 50 million & 20 & 11.30 \\
\hline \multirow{3}{*}{ Market presence in years } & up to 10 years & 57 & 32.20 \\
\hline & over 10 years to 20 years & 36 & 20.34 \\
\hline & over 20 years & 84 & 47.46 \\
\hline
\end{tabular}

Source: Own study.

Two statistical programs were used in the analysis process: R and SPSS. The following methods were applied: elements of descriptive statistics (statistical parameters in the form of mean, dominant), independence test $\chi^{2}$, Varimax factor analysis and Bartlett's sphericity test. Appropriate visualisation and tabulation of the obtained results were performed. Due to the necessity to separate the compared groups, it was necessary to define the independent variables (so-called grouping variables) and the dependent variable, which during the research were compared in the groups (Table 4). This analysis was conducted for all companies together and for individual, distinguished categories.

Table 4. Variables adopted in the research process.

\begin{tabular}{cc}
\hline Dependent Variables & Independent Variables \\
\hline enterprise size & scope of CSR activities carried out by enterprises \\
annual turnover & motives for implementing CSR concepts \\
time of presence on the market & barriers to implementing CSR concepts \\
capital ownership & benefits of implementing CSR concepts \\
& disadvantages of implementing CSR concepts \\
\hline
\end{tabular}
Source: Own study.

The application of the above research methods enabled the falsification of the research hypotheses.

\section{Results}

\subsection{Scope of Implementation}

In Poland, only 37\% of enterprises from the construction sector declare that they implement the principles of CSR. Considering three variables: company size, origin of capital, annual turnover and seniority in the market, the CSR principles are implemented mainly by large companies with foreign or mixed capital, high turnover and long market presence $[21,30,36]$. The conducted research indicates that between individual groups of enterprises, distinguished according to the above criteria, there are significant differences in the implementation of CSR principles. This allows us to maintain the first of the hypotheses made - the size of the enterprise, turnover, time on the market and origin of capital are the factors differentiating the degree of implementation of principles in individual areas of CSR $[7,42,47,53,54]$ (Table 5). 
Table 5. Implementation of CSR principles by Polish construction sector enterprises (\%).

\begin{tabular}{|c|c|c|c|c|c|c|c|c|c|c|c|c|}
\hline \multirow{2}{*}{ Description } & \multirow{2}{*}{ Total } & \multicolumn{3}{|c|}{ Company Size } & \multicolumn{2}{|c|}{ Origin of Capital } & \multicolumn{3}{|c|}{$\begin{array}{c}\text { Annual Turnover (EUR } \\
\text { Million) }\end{array}$} & \multicolumn{3}{|c|}{ Market Presence (Years) } \\
\hline & & Small & Medium & Large & Domestic & $\begin{array}{l}\text { Foreign and } \\
\text { Mixed }^{1}\end{array}$ & $\leq 10$ & $\begin{array}{l}>10 \\
\leq 50\end{array}$ & $>50$ & $\leq 10$ & $\begin{array}{l}>10 \\
\leq 20\end{array}$ & $>20$ \\
\hline Yes & 63 & 25 & 43 & 77 & 33 & 68 & 22 & 53 & 85 & 30 & 36 & 42 \\
\hline No & 37 & 75 & 57 & 23 & 67 & 32 & 78 & 47 & 15 & 70 & 64 & 58 \\
\hline $\mathrm{N}$ & 177 & 106 & 49 & 22 & 155 & 22 & 114 & 43 & 20 & 57 & 36 & 84 \\
\hline
\end{tabular}

Source: Own study. ${ }^{1}$ For the purposes of the study, two categories of capital were adopted. Therefore, the category of enterprises with only foreign capital was combined with the category of entities in which own and foreign capital is involved. The reason for this was that there were few companies with foreign capital in the sample.

Large enterprises are characterised by a different specificity of operations in the context of the implementation of CSR principles than medium and small enterprises. The independence test $\chi^{2}(\alpha=0.05)$ showed that there is a statistical dependence between enterprise size and the manner of CSR activities implementation. In the majority of small $(85 \%)$ and medium enterprises (71\%) that implement the CSR principles, these activities are not inscribed in their operational strategy. The situation is different in large enterprises$55 \%$ of them declare that CSR activities are included in their development strategy. A vast majority of small (91\%) and medium enterprises (94\%) do not plan and control their CSR activities in the light of the assumed effects. Despite the majority of large companies declare that they do not conduct similar activities either, their percentage is much lower- $59 \%$. Small companies $(94 \%)$ and medium-sized companies $(82 \%)$ generally do not employ persons responsible for implementation of CSR principles. Similarly, small $(97 \%)$ and medium-sized companies (80\%), in general, do not have information on their websites about their involvement in the CSR process. In contrast, large companies, employing more than 250 persons, have in their structures a person responsible for the implementation of CSR (59\%), as well as publish information on their involvement in CSR activities on their websites $(73 \%)$.

In small companies, there are no persons (specialists) directly involved in the implementation of CSR principles. The owner (56\%), or the management board (33\%) are mainly responsible for socially responsible activities. In medium companies, the management board $(45 \%)$ or the marketing department $(43 \%)$ deal with CSR. It looks differently in large enterprises, where CSR specialists are appointed-27\% of the surveyed entities in this category declared employing such a person. Moreover, similarly as in the case of medium enterprises, the management board (73\%) and the marketing department $(50 \%)$ are responsible for CSR activities. Other units indicated by the respondents, involved in the implementation of CSR principles were administration department, chief accountant, investment specialist, proxy, communication department, management of organisational units, all employees.

The above results allow us to support two further research hypotheses, that large enterprises undertake intentional, formalised activities, and their activity in this area may affect the organisational structure of the entity, and that small and medium enterprises implement postulates and principles of Corporate Social Responsibility to a large extent, in a non-formalised manner, and these activities are not an element of the company's strategy. The factors that allow to explain these differences are motivations, barriers and expected benefits related to the implementation of CSR.

\subsection{Motivations}

Representatives of Polish construction sector enterprises have various expectations as regards the effects of implementing CSR postulates. Most of them expect first of all an improvement in relations with society. Respondents assessed their motivations for implementing CSR principles on the basis of a Likert scale. They addressed each of the given barriers, assessing whether its importance is very high (value 5), high (4), medium (3), low (2), or very low (1). Respondents assigned an average value of 4.11 to this effect. In 
second place the respondents put image benefits, while financial effects may be distant in time (Figure 1)

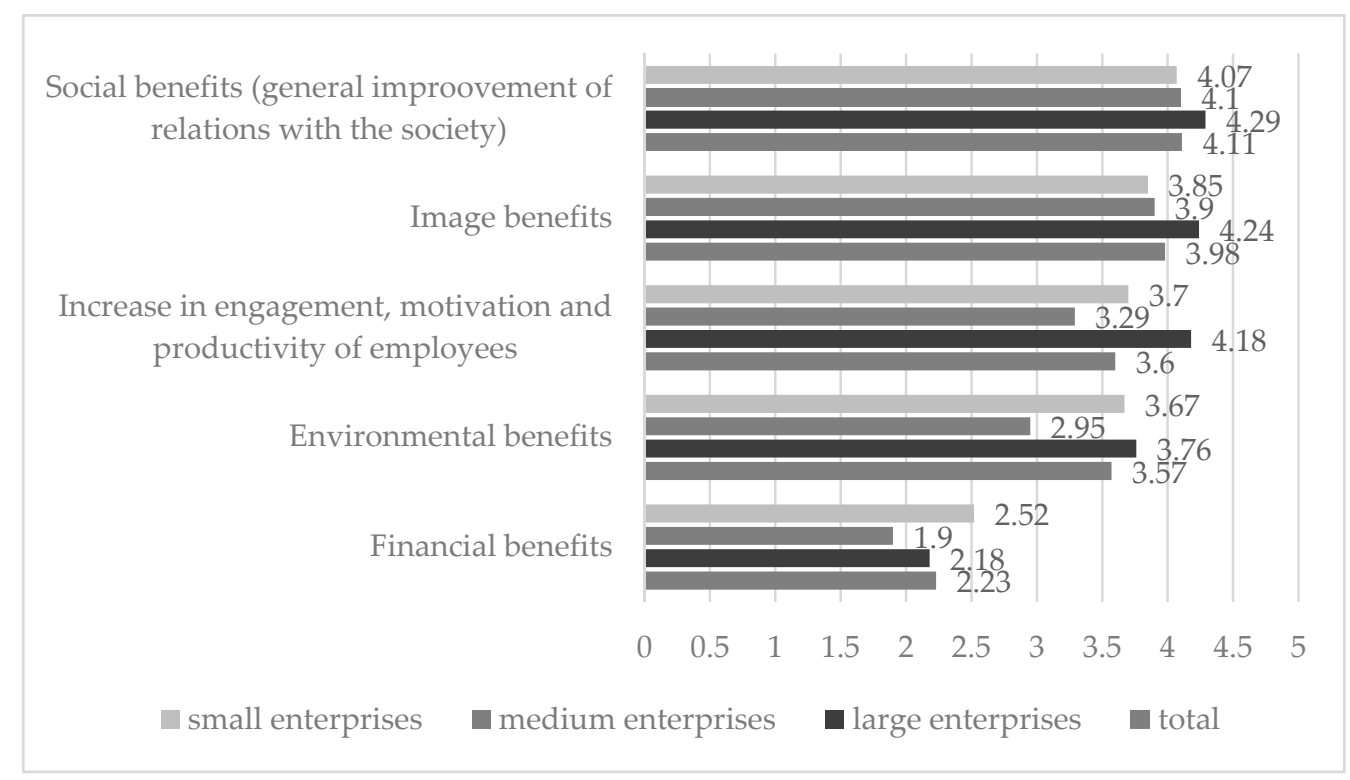

Figure 1. Expected benefits from implementation of CSR principles by Polish construction sector enterprises-importance assessment.

The indicated motivation may find their justification in the different perception of the construction sector. On the one hand, it is necessary for the success of investments and economic development, but on the other hand, it is not perceived as a safe and reliable employer [10-12]. No wonder then that managers strive to improve the image of the industry and first of all try to highlight social benefits, which also affect the immediate and further environment outside the enterprise. However, not all studies confirm such a marginal role of the financial factor, especially in smaller enterprises, it is of considerable importance, even if possible financial benefits are deferred in time $[20,46]$.

The above results allow to maintain the hypothesis that for large enterprises that implement CSR postulates, image benefits are very important, while financial benefits may be distant in time. It should be added, however, that also other benefits (social, environmental, organisational) are more important than the financial benefits expected as remote in time. It is also worth pointing out that this regularity concerns not only large enterprises, but also medium and small ones.

\subsection{Barriers}

The respondents assessed the barriers to implementing CSR principles according to the same scale as in the case of motivation. The main obstacles to running socially responsible business Polish enterprises from the construction sector see in lack of time and knowledge on the benefits of CSR. Another significant barrier for the respondents is also the lack of supporting and advisory institutions (Figure 2).

A great differentiation can be observed in the perception of barriers to the implementation of CSR principles by small, medium and large enterprises. Smaller enterprises perceive more barriers, to which they ascribe high and very high importance, than other enterprises. They perceive as many as 9 barriers, while in case of medium enterprises those are 3 , and in case of large enterprises -2 barriers (Table 6).

Small enterprises indicate the whole set related to the lack of awareness and knowledge in the scope of CSR, as well as the lack of resources (time, personnel) as barriers to the implementation of CSR principles. Lack of awareness, attributed first of all to the management staff, is also the basic barrier indicated by medium enterprises. The representatives of enterprises convince that they rather have adequate knowledge in the scope in question, 
although they are not aware of the benefits that their companies can obtain thanks to the implementation of CSR. However, the main barrier is the lack of time to deal with issues that are not at the core of current activities.

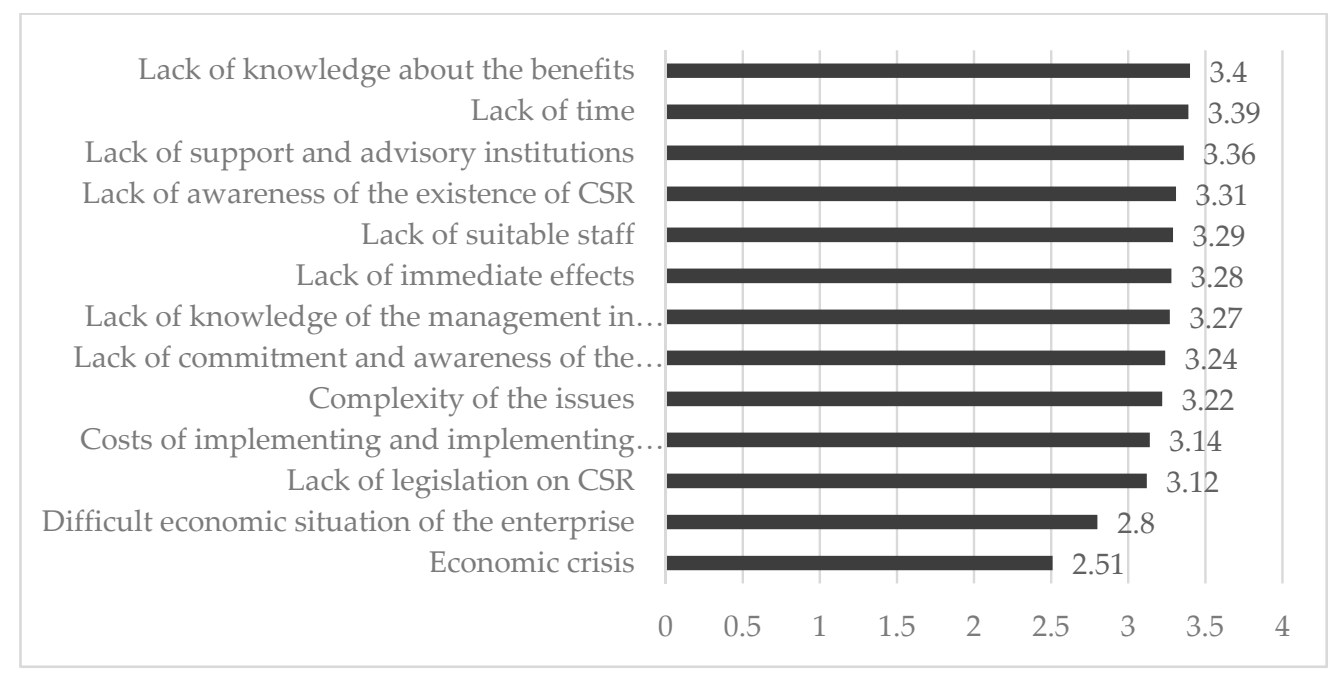

Figure 2. Barriers to implementation of CSR principles by Polish construction sector enterprisesimportance assessment.

Table 6. Frequency of assessments of individual barriers to implementation of CSR principles.

\begin{tabular}{ccccc}
\hline & & Barriers & \multicolumn{3}{c}{ Dominant } \\
\cline { 3 - 5 } No & & \multicolumn{3}{c}{ Companies } \\
\cline { 3 - 4 } & & 4 & 3 & 4 \\
\hline 1 & Lack of knowledge about the benefits & 5 & 3 & 5 \\
2 & Lack of time & 4 & 3 & 2 \\
3 & Lack of support and advisory institutions & 5 & 5 & 3 \\
4 & Lack of awareness of the existence of CSR & 4 & 3 & 3 \\
5 & Lack of suitable staff & 4 & 3 & 3 \\
6 & Lack of immediate effects & 4 & 4 & 3 \\
7 & Lack of knowledge of the management in this field & 4 & 3 \\
8 & Lack of commitment and awareness of the management & 4 & 3 \\
9 & Complexity of the issues & 3 & 3 & 3 \\
10 & Costs of implementing and implementing CSR & 3 & 3 & 3 \\
11 & Lack of legislation on CSR & 1 & 1 & 1 \\
12 & Difficult economic situation of the enterprise & 1 & 2 & 1 \\
13 & Economic crisis & & 3 & Large \\
\hline
\end{tabular}

Source: own study.

The reasons for this state of affairs are the limited resources, both financial and human resources, as well as the limited knowledge of people managing small companies. In the Polish reality, these are often people who simultaneously perform physical work, which they combine with company management, as a result they do not have enough time to perform additional tasks. Also, the perception of the benefits of implementing CSR seems quite distant to them, due to the number of current activities they are burdened with in their daily work.

Due to small differences between average values of variables, an in-depth analysis of factors describing barriers under consideration was performed. Its aim was to identify the most important and hidden factors that constitute barriers to the implementation of CSR principles. Large companies were excluded from the analysis due to their different specifics, and because of their small size in the conducted survey. For the purpose of the study, an exploratory factor analysis with Varimax rotation was used, which was preceded by 
testing the validity of its use. Bartlett's sphericity test was applied to assess the significance of the correlation matrix and the Kaiser-Mayer-Olkin (KMO) coefficient was determined. The Bartlett's test statistic $(U=1126.72)$ was greater than the critical value, which for the assumed significance level and 78 degrees of freedom was 99.6. The null hypothesis that all correlation coefficients are equal to zero should therefore be rejected. The degree of adequacy as measured by the KMO coefficient was 0.88 . This allowed the application of factor analysis. The principal component method with Varimax factor rotation was used to determine the factors. A determination of the number of factors was made using the Kaiser criterion. Factors with eigenvalues greater than 1 were left out. In the process of identifying factors that describe barriers to implementation of principles of Corporate Social Responsibility by small and medium construction enterprises in Poland, two eigenvalues were greater than 1, and allowed explaining about $61.7 \%$ of total variation. The factor corresponding to the first (largest) eigenvalue explains about 35\% of total variance, while the second component explains about $27 \%$ of total variance. According to the Kaiser criterion, only 2 factors should be left, which explain $61.7 \%$ of the total variance. The validity of the choice was also confirmed by the Cattel's criterion of scree. In the further part of the study, using the principal components method with Varimax rotation, factor loadings were calculated. Only significant factor loadings were considered, after rounding not smaller as to absolute value than 0.8 (Table 7).

Table 7. Factor loadings obtained using the principal components method after Varimax rotation.

\begin{tabular}{ccc}
\hline Variable & \multicolumn{2}{c}{ Component } \\
\cline { 2 - 3 } & $\mathbf{1}$ & $\mathbf{2}$ \\
\hline Lack of knowledge of the management in this field & 0.875 & - \\
Lack of support and advisory institutions & 0.873 & - \\
Difficult economic situation of the enterprise & - & 0.828 \\
Economic crisis & - & 0.824 \\
\hline
\end{tabular}

Source: own study.

Finally, in order to give an interpretation of the common factors, the variables that are correlated with each factor were separated. The variables 'lack of management knowledge in the subject' and 'lack of supporting and advisory institutions' have high factor loadings ( 0.875 and 0.873 respectively) with the first factor. The variables 'difficult economic situation of the enterprise' and 'economic crisis' in turn have high factor loadings (0.828 and 0.824 respectively) with the second factor.

The first of these factors is therefore determined by two important elements: the lack of knowledge of the management in this area and the lack of supporting and advisory institutions. Due to the variables that describe it, it was defined as 'limitations related to obtaining/possessing knowledge necessary to implement CSR principles'. The share of this factor in the total variance of variables included in the study was 35\%. The second factor, in turn, is described by two elements: the difficult economic situation of the enterprise and the economic crisis and was defined as 'constraints related to the economic situation inside and outside the enterprise'. The share of this factor in the total variance of variables included in the study exceeded $26 \%$.

The above analysis allows us to sustain another hypothesis stating that the main barriers related to the implementation of CSR in small and medium enterprises refer to limitations in the area of knowledge in the subject matter.

This is also confirmed by the previously formulated conclusions resulting from the current limitations of the management staff and is partially reflected in the literature on the subject, including studies relating to other countries and sectors [16,36,42,47].

\subsection{Benefits}

Actual benefits obtained as a result of CSR implementation can be divided into two categories, taking into account their significance for the enterprise, expressed by the 
assessed ones in the Lickert scale (1-very low significance, . . , 5-very high significance). The first group consists of benefits, which are ascribed high or very high importance. In Table 8 . these are the benefits presented in positions 1-9. The second group consists of benefits, which were ascribed low importance (items 10-13). Quite high consistency in this case between companies of different size categories is noticeable. The only exception is increased sales of services. Small companies see this as a very important benefit. Companies in the other two categories attribute little or very little importance to it. This is probably related to the fact that small enterprises, having implemented CSR principles, could become cooperators (subcontractors, partners in tenders) for medium and large enterprises implementing these principles.

Table 8. Frequency of assessments of individual benefits from implementation of CSR principles.

\begin{tabular}{|c|c|c|c|c|}
\hline \multirow{3}{*}{ No } & \multirow{3}{*}{ Benefits } & \multirow{2}{*}{\multicolumn{3}{|c|}{$\begin{array}{c}\text { Dominant } \\
\text { Companies }\end{array}$}} \\
\hline & & & & \\
\hline & & Small & Medium & Large \\
\hline 1 & Increase in sales of services & 5 & 1 & 2 \\
\hline 2 & Enhancing the enterprise's good external image & 4 & 4 & 4 \\
\hline 3 & Solving an urgent/important social problem & 4 & 4 & 3 \\
\hline 4 & Increased trust on the part of local authorities & 4 & 3 & 3 \\
\hline 5 & $\begin{array}{l}\text { Increased motivation and identification of employees with } \\
\text { the company }\end{array}$ & 4 & 3 & 4 \\
\hline 6 & $\begin{array}{c}\text { Contribution to the improvement of environmental } \\
\text { protection }\end{array}$ & 4 & 3 & 4 \\
\hline 7 & Increase in investors' interest & 3 & 4 & 4 \\
\hline 8 & Increase in competitiveness & 3 & 4 & 3 \\
\hline 9 & Improving relations with the local community & 3 & 4 & 4 \\
\hline 10 & Increase in the enterprise's profitability & 2 & 1 & 2 \\
\hline 11 & Better access to financial capital & 1 & 1 & 2 \\
\hline 12 & Introduction/enhancement of environmental technologies & 1 & 1 & 3 \\
\hline 13 & $\begin{array}{l}\text { Application of CSR principles by suppliers and } \\
\text { subcontractors }\end{array}$ & 1 & 1 & 3 \\
\hline
\end{tabular}

Source: own study.

On the other hand, the only disadvantage that the respondents ascribe significant importance to is the generation of high costs. It is particularly noticeable by entities from the group of small enterprises (Table 9).

In light of the above findings, the hypothesis that owners and managers of small construction enterprises perceive CSR activities only as a cost that will not result in any additional benefits should only be partially supported. It is true that CSR activities are perceived by small enterprises as capital intensive. However, these companies also perceive benefits from the implementation of CSR principles, attribute great importance to it and indicate increased sales of services as the most important one.

However, it is still a kind of financial motivator, though not a direct one, so with regard to small enterprises their economic condition is a determinant of choices. These are not companies that have the technical and organizational possibility to "devote" some resources or delegate them to other activities indirectly related to the company's operations. They are too small and too focused on their current activities. This is an important signal to those responsible for advice and lawmaking. Perhaps solutions supporting small enterprises in this area, or imposing specific legal requirements on them, may persuade their owners to broaden their activities in the area of CSR $[16,19,36,47]$. 
Table 9. Frequency of assessing particular disadvantages of implementing CSR principles.

\begin{tabular}{|c|c|c|c|c|}
\hline \multirow{3}{*}{ No } & \multirow{3}{*}{ Disadvantages } & \multirow{2}{*}{\multicolumn{3}{|c|}{$\begin{array}{c}\text { Dominant } \\
\text { Companies }\end{array}$}} \\
\hline & & & & \\
\hline & & Small & Medium & Large \\
\hline 1 & \multirow{3}{*}{$\begin{array}{c}\text { Generating high costs } \\
\text { Reduction of the enterprise's efficiency } \\
\text { Lack of public understanding and broader acceptance of such } \\
\text { activities }\end{array}$} & 4 & 3 & 3 \\
\hline 2 & & 2 & 1 & 1 \\
\hline 3 & & 1 & 1 & 2 \\
\hline 4 & $\begin{array}{l}\text { Conflicts between different stakeholder groups about their } \\
\text { own interests }\end{array}$ & 1 & 1 & 2 \\
\hline 5 & Reduction of competitiveness on the market & 1 & 1 & 1 \\
\hline 6 & Restriction of the enterprise's development & 1 & 1 & 1 \\
\hline 7 & Departure from the profit maximisation principle & 1 & 2 & 1 \\
\hline
\end{tabular}

\section{Discussion}

Our conclusions confirm some of the observations resulting from research appearing in publications on CSR in the construction industry in other countries [12,23,45,51,53]. Even publications containing research results of a causal nature or providing only an indicative, rather than a conclusive, trend of CSR in construction, contain similar insights [24]. Thus, it can be concluded that regardless of the place where the study was conducted (country, region) and the method adopted (full survey, random sample, purposive selection, pilot study), certain general regularities are consistently confirmed. The most important of these include:

- the existence of a large potential in the implementation of CSR in construction industry enterprises. Our study confirmed that less than $40 \%$ of enterprises in Poland consciously implement it, which also translates to the results of other researchers regarding other countries $[62,63]$ and confirms that this is an industry where there is a great need for such activities [64];

- the significant dependence of potential and motivation in implementing CSR on company size, turnover, seniority, and origin of capital. The general regularity is that the larger the enterprise and the higher the share of foreign capital (presumably a higher level of internationalisation), the higher the propensity and effectiveness of implementing measures (Table 10);

- the perception of benefits from the implementation of CSR is related to the size of the enterprise, the only benefit that is 'strengthening the enterprise's image outside' was indicated as significant by enterprises from each of the size ranges, the others show greater differentiation. Similar conclusions were reached i.a. by Laudal [30], Santoso and Feliana [65] or Graafland [66].

It strongly confirms the often-raised fact that one of the key barriers to CSR implementation is insufficient knowledge of entrepreneurs $[50,55]$. It mainly concerns the benefits as well as the barriers of extending the responsibility of the business with a social component. Knowledge deficiencies are manifested, on the one hand, in the lack of information on the benefits that can be derived by implementing CSR in the enterprise, as well as in the lack of awareness of CSR in general (this is a particularly striking finding), as well as in the knowledge and competence deficiencies of top management and executives and rank-and-file employees. The scope also extends outside the enterprise. Some entities see the difficulty or even the impossibility of implementing CSR in the lack of supporting and advisory institutions. This is a problem that concerns small enterprises to the greatest extent. In the case of motivations to undertake activities in the area of social responsibility, motivations related to organizational culture and awareness are identified to a limited extent for these enterprises: core business value, personal values of the founder or entrepreneur, ethical beliefs and consideration, doing the right thing, business imperatives. It can be confirmed by the practices identified in small and medium-sized enterprises in other countries. 
Table 10. The conceptualization of motivations and barriers of implementing CSR in the construction sector in developing and developed countries vs. its operationalization in Poland.

\begin{tabular}{ccc}
\hline Category & Most Frequent Attributes & Most Frequent Attributes in Poland \\
\hline Motivations & $\begin{array}{c}\text { Branding, image management, public reputation; Public } \\
\text { expectation/pressure, media pressure; Organizational } \\
\text { culture and awareness: core business value, personal values } \\
\text { of the founder or entrepreneur, ethical beliefs and } \\
\text { consideration, doing the right thing, business imperatives } \\
\text { Lack of awareness, knowledge, and information within the } \\
\text { organization; Lack of capacity and expertise; Lack of } \\
\text { Barriers }\end{array}$ & $\begin{array}{c}\text { Social benefits, image benefits, increase in } \\
\text { engagement, motivation and productivity of } \\
\text { employees, environmental benefits, financial } \\
\text { benefits }\end{array}$ \\
& $\begin{array}{c}\text { Lack of knowledge, time, support and advisory } \\
\text { from senion leaders or managers within the organization; } \\
\text { The negative attitude within the organization }\end{array}$ & $\begin{array}{c}\text { CSR; Lack of suitable staff; Lack of immediate } \\
\text { effects; Complexity of the issues; Costs; Lack of } \\
\text { legislations }\end{array}$ \\
\hline
\end{tabular}

Source: own work and own elaboration according to [53,54].

The positively verified and confirmed hypothesis, stating that small and mediumsized enterprises implement the postulates and principles of corporate social responsibility largely in an informal way, is reflected, i.a. in the research of Bevan and Yung [59]. They demonstrate that a number of companies of this size incorporate some aspects of CSR into their business activities even though they do not refer to the practices as CSR, as none of them have a formal CSR policy in place. At the same time, quite strong motivations, and significant benefit potential cause enterprises to nevertheless decide, to varying degrees, to implement CSR elements in their day-to-day operations. However, they do not perceive as dominating the benefit that would eliminate the basic obstacles, i.e., raising awareness of the management and employees, expanding knowledge or acquiring new competences. Thus, no links are observed between benefits and opportunities to eliminate barriers-they occur in completely different areas. Most of the motivations are of an external nature, they are not focused on the internal situation of the enterprise and the condition of its staff. Companies rather pay attention to image benefits, financial benefits (although they allow for their distance in time), as well as social or environmental benefits. An indirect relation can only be observed between internal benefits (increased involvement, motivation, and productivity of employees) and the potential for raising employee awareness as a tool for eliminating barriers related to the lack of knowledge and competence. It can also be assumed that entrepreneurs perceive the area of raising competences as a necessary condition for the implementation of CSR, thus they do not assess it as a benefit of the whole process.

As a result of the conducted research, the hypotheses posed at the outset were positively verified and referred to: (1) key parameters differentiating the degree of CSR implementation in enterprises in the construction sector in Poland, which include-enterprise size, turnover, time of market presence and origin of capital, (2) purposefulness and degree of formalisation of activities in the scope of CSR implementation-in large enterprises these attributes are characteristic, while small and medium enterprises implement postulates and principles of Corporate Social Responsibility to a large extent in an informal manner, (3) scope of key benefits that enterprises indicate in connection with the implementation of CSR-for large enterprises, image benefits are very important, while financial benefits may be delayed in time, postponement of possible financial benefits is also admitted by small and medium enterprises, (4) barriers and difficulties in implementing CSR - which in small and medium enterprises refer to limitations in the area of knowledge in the subject matter, as often owners and managers of small construction enterprises perceive CSR activities exclusively as costs that will not bring any additional benefits. These are indications that show a high degree of convergence with the results of other studies conducted worldwide in relation to construction enterprises. The problems and barriers to implementing CSR are universal and depend more on the scale and level of internationalisation (in our study determined by the source of capital) than on the place of conducting business. 


\section{Conclusions}

The conducted research aimed to identify the role that CSR principles play in the activities of Polish enterprises in the construction sector. An attempt was made to determine the degree of implementation of CSR postulates, identify the motives that construction enterprises follow when deciding to implement CSR principles, identify barriers and determine the effects of implementation of CSR principles by construction enterprises. At the beginning of the research, it was assumed that the variables differentiating the behaviour of Polish construction sector enterprises towards CSR requirements are: the size of employment, annual turnover, capital ownership and time of market presence.

The results obtained may constitute an important premise for decision-makers at the management level and for legislation, allowing to create better conditions for the development of CSR in the construction industry. However, further research should be of a slightly more qualitative nature and, as a result of in-depth analyzes (in the form of in-depth interviews combined with the Delphi method), to clearly identify the causes of differences and motivations.

The general conclusion that emerges as a result of the conducted research is the need for systemic support of the process of popularisation and implementation of CSR in enterprises of the construction industry. The specificity of the industry indicated in the introduction, often emphasised by many authors concerned with this issue, manifesting itself i.a. in the high level of risk, the importance of safety procedures, the large number of business partners and the significance of the sector in the overall economy, requires special attention to be paid to this issue. Moreover, both in Poland and in a number of other countries, the sector is dominated by small and medium enterprises, which are at a disadvantage when it comes to the advancement of CSR processes in day-to-day operations. Systemic, legislative and, above all, popularisation support could contribute to a systematic change of this state of affairs. As raised by Xia et al. [58] (p. 350) it is necessary to 'Create the avenue to build on the existing knowledge of CSR in the construction industry.' Otherwise, further research on the issue will be continually burdened by deficits in competence and knowledge, and the effectiveness and benefits of implementation will, especially for small and medium-sized enterprises, be judged on the basis of actions taken in a disorganised, haphazard or occasional manner.

Author Contributions: Conceptualization, A.B. (Arnold Bernaciak), M.H. and A.B. (Anna Bernaciak); methodology, A.B. (Arnold Bernaciak) and M.H.; software, M.H.; validation, A.B. (Arnold Bernaciak), M.H. and A.B. (Anna Bernaciak); formal analysis, A.B. (Arnold Bernaciak), M.H. and A.B. (Anna Bernaciak); investigation, A.B. (Arnold Bernaciak), M.H. and A.B. (Anna Bernaciak); resources, A.B. (Arnold Bernaciak), M.H. and A.B. (Anna Bernaciak); data curation, M.H.; writing—original draft preparation, A.B. (Arnold Bernaciak), M.H. and A.B. (Anna Bernaciak); writing-review and editing, A.B. (Arnold Bernaciak) and A.B. (Anna Bernaciak); visualization, A.B. (Arnold Bernaciak) and A.B. (Anna Bernaciak); supervision, A.B. (Arnold Bernaciak) and A.B. (Anna Bernaciak); project administration, A.B. (Arnold Bernaciak). All authors have read and agreed to the published version of the manuscript.

Funding: This research received no external funding.

Institutional Review Board Statement: Not applicable.

Informed Consent Statement: Not applicable.

Data Availability Statement: The data are available upon the request from the corresponding author.

Conflicts of Interest: The authors declare no conflict of interest.

\section{References}

1. Lou, E.C.W.; Lee, A.; Mathison, G. Recapitulation of corporate social responsibility (CSR) for construction SMEs in the UK. In Proceedings of the 27th Annual ARCOM Conference, Bristol, UK, 5-7 September 2011; Egbu, C., Lou, E.C.W., Eds.; Association of Researchers in Construction Management: Bristol, UK, 2011; pp. 673-682.

2. Glass, J. The state of sustainability reporting in the construction sector. Smart Sustain. Built Environ. 2012, 1, 87-104. [CrossRef] 
3. Oladinrin, T.O.; Ogunsemi, D.R.; Aje, I.O. Role of Construction Sector in Economic Growth: Empirical Evidence from Nigeria. FUTY J. Environ. 2012, 7, 50-60. [CrossRef]

4. Yılmaz, M.; Bakış, A. Sustainability in Construction Sector. Procedia Soc. Behav. Sci. 2015, 195, 2253-2262. [CrossRef]

5. Seriki, O.O. Looking through the African lenses: A critical exploration of the CSR activities of Chinese International Construction Companies (CICCs) in Africa. Int. J. Corp. Soc. Responsib. 2020, 5, 8. [CrossRef]

6. Martinuzzi, A.; Kudlak, R.; Faber, C.; Wiman, A. CSR Activities and impacts of the construction sector. RIMAS Work Pap. 2011, $1,1-28$.

7. Bal, M.; Bryde, D.; Fearon, D.; Ochieng, E. Stakeholder Engagement: Achieving Sustainability in the Construction Sector. Sustainability 2013, 5, 695-710. [CrossRef]

8. Zhao, Z.-Y.; Zhao, X.-J.; Davidson, K.; Zuo, J. A corporate social responsibility indicator system for construction enterprises. J. Clean. Prod. 2012, 29, 277-289. [CrossRef]

9. Halaburda, M.; Bernaciak, A. Environmental protection in the perspective of CSR activities undertaken by polish enterprises of the construction industry. Econ. Environ. 2020, 75, 122-133. [CrossRef]

10. Zou, P.X.; Couani, P. Managing risks in green building supply chain. Arch. Eng. Des. Manag. 2012, 8, 143-158. [CrossRef]

11. Close, R.; Loosemore, M. Breaking down the site hoardings: Attitudes and approaches to community consultation during construction. Constr. Manag. Econ. 2014, 32, 816-828. [CrossRef]

12. Jiang, W.; Wong, J.K. Key activity areas of corporate social responsibility (CSR) in the construction industry: A study of China. J. Clean. Prod. 2016, 113, 850-860. [CrossRef]

13. Burlea, A.S.; Popa, I. Legitimacy Theory. In Encyclopedia of Corporate Social Responsibility; Idowu, S.O., Capaldi, N., Zu, L., Gupta, A.D., Eds.; Springer: Berlin/Heidelberg, Germany, 2013; Volume 21, pp. 1579-1584.

14. Bebbington, J.; Larrinaga-González, C.; Moneva-Abadía, J.M. Legitimating reputation/the reputation of legitimacy theory. Account. Audit. Account. J. 2008, 21,371-374. [CrossRef]

15. Janang, J.S.; Joseph, C.; Said, R. Corporate Governance and Corporate Social Responsibility Society Disclosure: The Application of Legitimacy Theory. Int. J. Bus. Soc. 2020, 21, 660-678. [CrossRef]

16. Bartkowiak, G.; Wyrwicka, M.K.; Krugiełka, A. Socially responsible activities in medium-sized enterprises and their perception by students and graduates of selected universities in Greater Poland. Manag. Probl. 2010, 8, 182-201.

17. Oczkowska, R. The Development and Implementation of CSR in Polish Retailing. Zeszyty Naukowe Uniwersytetu Ekonomicznego w Krakowie. Sci. J. Krakow Univ. Econ. 2012, 880, 79-93.

18. Ratajczak, M.; Wołoszyn, J.; Stawicka, E. Concept of CSR in the aspect of employees on the example of agribusiness enterprises from Mazowieckie Voivodeship. Polityka ekonomiczna. Prace Naukowe UE we Wrocławiu. Res. Pap. Wroctaw Univ. Econ. Econ. Policy 2012, 246, 381-390.

19. Rogowski, R. The Practice of CSR Implementation in Polish Companies According to the CSR Advisors. Annales. Etyka w życiu gospodarczym (Ann. Ethics Econ. Life) 2016, 19, 37-54. [CrossRef]

20. Piskalski, G. Społeczna Odpowiedzialność Biznesu w Polskich Realiach. Teoria a Praktyka, Raport z Monitoringu Społecznej Odpowiedzialności Największych Polskich Przedsiębiorstw (Corporate Social Responsibility in the Polish Reality. Theory and Practice, Report on the Monitoring of the Social Responsibility of the Largest Polish Enterprises); Fundacja CentrumCSR.PL: Warszawa, Poland, 2015.

21. Ratajczak, M. Implementation of key components of CSR concept in small and medium-sized enterprises of agribusiness from Lesser Poland. Pr. Nauk. Uniw. Ekon. We Wroctawiu 2015, 402, 307-317.

22. Gołata, K. Corporate social responsibility and the destruction of the company's image. Legal Econ. Sociol. Mov. 2017, 79, 215-224.

23. European Commission. Communication from the Commission to the European Parliament and the Council. Strategy for the Sustainable Competitiveness of the Construction Sector and Its Enterprises. Available online: https:/ / eur-lex.europa.eu/legalcontent/EN/TXT/?uri=celex:52012DC0433 (accessed on 27 August 2021).

24. Loosemore, M.; Lim, B.T.H. Linking corporate social responsibility and organizational performance in the construction industry. Constr. Manag. Econ. 2017, 35, 90-105. [CrossRef]

25. Liston-Heyes, C.; Ceton, G.C. Corporate social performance and politics: Do liberals do more? J. Corp. Citizensh. 2007, 25, 95-108. [CrossRef]

26. Fontana, E. Strategic CSR: A panacea for profit and altruism? An empirical study among executives in the Bangladeshi RMG supply chain. Eur. Bus. Rev. 2017, 29, 304-319. [CrossRef]

27. Balabanis, G.; Phillips, H.C.; Lyall, J. Corporate social responsibility and economic performance in the top British companies: Are they linked? Eur. Bus. Rev. 1998, 98, 25-44. [CrossRef]

28. Papasolomou-Doukakis, I.; Krambia-Kapardis, M.; Katsioloudes, M. Corporate social responsibility: The way forward? Maybe not! A preliminary study in Cyprus. Eur. Bus. Rev. 2005, 17, 263-279. [CrossRef]

29. Santos, M.J. CSR in SMEs: Strategies, practices, motivations and obstacles. Soc. Responsib. J. 2011, 32, 553-572. [CrossRef]

30. Laudal, T. Drivers and barriers of CSR and the size and internationalization of firms. Soc. Responsib. J. 2011, 7, 234-256. [CrossRef]

31. Angus-Leppan, T.; Metcalf, L.; Benn, S. Leadership Styles and CSR Practice: An Examination of Sensemaking, Institutional Drivers and CSR Leadership. J. Bus. Ethics 2010, 93, 189-213. [CrossRef]

32. Dhanesh, G.S. Why Corporate Social Responsibility? An Analysis of Drivers of CSR in India. Manag. Commun. Q. 2015, 29, 114-129. [CrossRef] 
33. Rodríguez Bolívar, M.P.; Garde Sánchez, R.; López Hernández, A.M. Managers as drivers of CSR in state-owned enterprises. J. Environ. Plan. Manag. 2015, 58, 777-801. [CrossRef]

34. Graafland, J.; Smid, H. Decoupling Among CSR Policies, Programs, and Impacts: An Empirical Study. Bus. Soc. 2019, 58, 231-267. [CrossRef]

35. Nadeem, A.; Kakakhel, S.J. An exploratory evidence of practice, motivations, and barriers to corporate social responsibility (CSR) in small and medium enterprises (SMEs) of Khyber Pakhtunkhwa Pakhtunkhwa (KPK). Abasyn J. Soc. Sci. 2016, 9, 479-494.

36. Cera, G.; Belas, J.; Marousek, J.; Cera, E. Do size and age of small and medium-sized enterprises matter in corporate social responsibility? Econ. Sociol. 2020, 13, 86-99. [CrossRef] [PubMed]

37. Kudłak, R. Instytucjonalne uwarunkowania społecznej odpowiedzialności biznesu (Institutional Determinants of Corporate Social Responsibility). Ph.D. Thesis, Wydawnictwo Naukowe UAM, Poznań, Poland, 2018.

38. Albareda, L.; Lozano, J.M.; Tencati, A.; Midttun, A.; Perrini, F. The changing role of governments in corporate social responsibility: Drivers and responses. Bus. Ethics A Eur. Rev. 2008, 17, 347-363. [CrossRef]

39. Jean, R.-J.; Wang, Z.; Zhao, X.; Business, R.R.S.A.M. Drivers and customer satisfaction outcomes of CSR in supply chains in different institutional contexts. Int. Mark. Rev. 2016, 33, 514-529. [CrossRef]

40. Russo-Spena, T.; Tregua, M.; De Chiara, A. Trends and Drivers in CSR Disclosure: A Focus on Reporting Practices in the Automotive Industry. J. Bus. Ethic 2016, 151, 563-578. [CrossRef]

41. O'Brien, I.M.; Ouschan, R.; Jarvis, W.; Soutar, G.N. Drivers and relationship benefits of customer willingness to engage in CSR initiatives. J. Serv. Theory Pract. 2020, 30, 5-29. [CrossRef]

42. D'Amato, A.; Falivena, C. Corporate social responsibility and firm value: Do firm size and age matter? Empirical evidence from European listed companies. Corp. Soc. Responsib. Environ. Manag. 2020, 27, 909-924. [CrossRef]

43. Chang, A.S.; Canelas, C.; Chen, Y.-L. Relationships between Environmental Initiatives and Impact Reductions for Construction Companies. Sustainability 2021, 13, 8061. [CrossRef]

44. Burlea-Schiopoiu, A.; Mihai, L.S. An Integrated Framework on the Sustainability of SMEs. Sustainability 2019, 11, 6026. [CrossRef]

45. Zahidy, A.A.; Sorooshian, S.; Abd Hamid, Z. Critical Success Factors for Corporate Social Responsibility Adoption in the Construction Industry in Malaysia. Sustainability 2019, 11, 6411. [CrossRef]

46. Popescu, C.R.G. Corporate Social Responsibility, Corporate Governance and Business Performance: Limits and Challenges Imposed by the Implementation of Directive 2013/34/EU in Romania. Sustainability 2019, 11, 5146. [CrossRef]

47. Badulescu, A.; Badulescu, D.; Saveanu, T.; Hatos, R. The Relationship between Firm Size and Age, and Its Social Responsibility Actions-Focus on a Developing Country (Romania). Sustainability 2018, 10, 805. [CrossRef]

48. Graafland, J.; van de Ven, B. Strategic and moral motivation for corporate social responsibility. J. Corp. Citizensh. 2006, 22, 111-123. [CrossRef]

49. Grimstad, S.M.F.; Glavee-Geo, R.; Fjørtoft, B.E. SMEs motivations for CSR: An exploratory study. Eur. Bus. Rev. 2020, 32, 553-572. [CrossRef]

50. Graafland, J.; Kaptein, M.; Mazereeuw, C. Motives of socially responsible business conduct. Macroeconomics 2010, 74, 1-23. [CrossRef]

51. Watts, G.; Dainty, A.; Fernie, S. Making sense of CSR in construction: Do contractor and client perceptions align. In Proceedings of the 31st Annual ARCOM Conference, Lincoln, UK, 7-9 September 2015.

52. Murphy, M.; Eadie, R. Socially responsible procurement. A service innovation for generating employment in contruction. Built Environ. Proj. Asset Manag. 2019, 9, 138-152. [CrossRef]

53. Zhang, Q.; Oo, B.L.; Lim, B.T.H. Drivers, motivations, and barriers to the implementation of corporate social responsibility practices by construction enterprises: A review. J. Clean. Prod. 2019, 210, 563-584. [CrossRef]

54. Zhang, Q.; Lim, B.T.H.; Oo, B.L. Drivers, Motivations and Barriers for Being a Socially Responsible Firm in Construction: A Critical Review. In Proceedings of the International Workshop on Environmental Management, Science and Engineering (IWEMSE 2018), Xiamen, China, 10-25 January 2018; pp. 568-575.

55. Abdul, Z.; Ibrahim, S. Executive and management attitudes towards corporate social responsibility in Malaysia. Corp. Gov. Int. J. Bus. Soc. 2002, 2, 10-16. [CrossRef]

56. Elving, W.J. Scepticism and corporate social responsibility communications: The influence of fit and reputation. J. Mark. Commun. 2013, 19, 277-292. [CrossRef]

57. Connors, S.; Anderson-Macdonald, S.; Thomson, M. Overcoming the 'Window Dressing' Effect: Mitigating the Negative Effects of Inherent Skepticism Towards Corporate Social Responsibility. J. Bus. Ethics 2017, 145, 599-621. [CrossRef]

58. Xia, B.; Olanipekun, A.; Chen, Q.; Xie, L.; Liu, Y. Conceptualising the state of the art of corporate social responsibility (CSR) in the construction industry and its nexus to sustainable development. J. Clean. Prod. 2018, 195, 340-353. [CrossRef]

59. Russo, A.; Perrini, F. Investigating Stakeholder Theory and Social Capital: CSR in Large Firms and SMEs. J. Bus. Ethics 2010, 91, 207-221. [CrossRef]

60. Nigri, G.; Del Baldo, M. Sustainability Reporting and Performance Measurement Systems: How do Small—And Medium-Sized Benefit Corporations Manage Integration? Sustainability 2018, 10, 4499. [CrossRef]

61. Bazarnik, J.; Grabiński, T.; Kąciak, E.; Mynarski, S.; Sagan, A. Badania Marketingowe. Metody i Oprogramowanie Komputerowe (Marketing Research. Computer Methods and Software); Canadian Consortium of Management Schools, Akademia Ekonomiczna w Krakowie: Warszawa-Kraków, Poland, 1992. 
62. Bevan, E.A.M.; Yung, P. Implementation of corporate social responsibility in Australian construction SMEs. Eng. Constr. Archit. Manag. 2015, 22, 295-311. [CrossRef]

63. Kucharska, W.; Kowalczyk, R. How to achieve sustainability?-Employee's point of view on company's culture and CSR practice. Corp. Soc. Responsib. Environ. Manag. 2019, 26, 453-467. [CrossRef]

64. Olanipekun, A.O.; Oshodi, O.S.; Darko, A.; Omotayo, T. The state of corporate social responsibility practice in the construction sector. Smart Sustain. Built Environ. 2020, 9, 91-111. [CrossRef]

65. Santoso, A.H.; Feliana, Y.K. The Association Between Corporate Social Responsibility And Corporate Financial Performance. Issues Soc. Environ. Account. 2014, 8, 82-103. [CrossRef]

66. Graafland, J. Does Corporate Social Responsibility Put Reputation at Risk by Inviting Activist Targeting? An Empirical Test among European SMEs. Corp. Soc. Responsib. Environ. Manag. 2017, 25, 1-13. [CrossRef] 